\title{
The inhibitory effect of glucagon-like peptide- 1 (GLP-1) 7-36 amide on gastric acid secretion in humans depends on an intact vagal innervation
}

\author{
A Wettergren, M Wøjdemann, S Meisner, F Stadil, J J Holst
}

\begin{abstract}
Background-Glucagon-like peptide-1 (GLP-1)(7-36) amide is an intestinal incretin hormone which also inhibits gastric acid secretion in humans. Its mechanism of action is unclear, but it strongly inhibits vagally induced secretion (sham feeding), suggesting that it could influence vagal activity.

Aim/Methods-The effect of intravenous GLP-1 (7-36 amide) (1 $\mathrm{pmol} / \mathrm{kg} / \mathrm{min})$ was studied on pentagastrin induced acid secretion in otherwise healthy subjects, previously vagotomised for duodenal ulcer $(n=8)$ and in a group of young $(n=8)$ and old $(n=6)$ healthy volunteers.

Results-Pentagastrin increased acid secretion significantly in all three groups, but the plateau concentration in the vagotomised subjects was lower than in controls. Infusion of GLP-1 (7-36 amide) significantly inhibited acid secretion in the control groups (to 67 (SEM 6) and 74 (SEM 3) \% of plateau concentrations in young and old controls, respectively) but had no effect in the vagotomised subjects. Differences in plasma concentrations of GLP-1 (7-36 amide), recovery of gastric marker, duodenal regurgitation, or Helicobacter pylori status could not explain the lack of effect. Blood glucose was lowered equally by GLP-1 (7-36 amide) in all subjects.
\end{abstract}

Conclusion-The inhibitory effect of GLP-1 (7-36 amide) on acid secretion depends on intact vagal innervation of the stomach.

(Gut 1997; 40: 597-601)

Gastrointestinal

Surgery C,

Rigshospitalet,

Copenhagen, Denmark

A Wettergren

$M$ Wøjdemann

S Meisner

F Stadil

Department of Medical

Physiology C,

University of

University of

Copenhagen, Denmark

J J Holst

Correspondence to:

Dr J J Holst,

Department of Medical

Physiology,

The Panum Institute,

Blegdamsvej 3,

DK 2200 Copenhagen $\mathrm{N}$, Denmark.

Accepted for publication

28 November 1996 secretion including meal and pentagastrin stimulated acid secretion. ${ }^{16-18}$ It has, therefore, been suggested to act as an important enterogastrone in humans. ${ }^{16-18}$

It is not clear by what mechanism(s) GLP-1 (7-36 amide) inhibits acid secretion in humans. Conceivably, it might act locally by inhibiting parietal cell secretion directly or indirectly via a paracrine action of an increased release of somatostatin. It might also act by inhibiting vagal transmission to the parietal cells at the gastric level or by inhibiting vagal efferent activity via a central mechanism. Recent experiments in our laboratory have shown that GLP-1 (7-36 amide) in physiological concentrations almost abolished acid secretion induced by sham feeding, indicating that GLP-1 (7-36 amide) effectively also inhibits neurally induced acid secretion. ${ }^{19}$

To determine whether the inhibitory effect of GLP-1 (7-36 amide) on acid secretion is exerted at the gastric level or whether it involves mainly neural mechanisms we have investigated its effects on pentagastrin induced acid secretion in patients previously treated for duodenal ulcer disease by selective vagotomy.

\section{Methods}

\section{SUBJECTS}

Two women and six men, mean age 67 (SEM 3) years, who were operated on for an uncomplicated duodenal ulcer in the period 1964-71 were studied. All had had a selective vagotomy and pyloroplasty a.m. HeinekeMikulicz. The vagotomy was considered complete in all patients as evidenced by more than $90 \%$ reduction in insulin induced peak acid output three months and five years after the operation. Since the operation none of the subjects has had a history of recurrent ulcer disease or signs of gastric outlet obstruction. Because of the age of the vagotomised subjects, two groups of control subjects were also investigated. One consisted of three women and five men, mean age 23 (SEM 1) years, the other comprised five men and one women, mean age 61 (SEM 2) years. All subjects were investigated for infection with Helicobacter pylori using a serological method. ${ }^{20}$ The study was approved by the local ethics committee of Copenhagen and Fredriksberg County. Written informed consent was obtained from all volunteers before the study. 
PEPTIDE

Synthetic, human GLP-1 (7-36 amide) was purchased from Peninsula (Peninsula Laboratories, Merseyside, St Helens, UK). The peptide was dissolved in $0.9 \%$ saline containing $1 \%$ human serum albumin (Albumin Nordisk, Novo Nordisk, Gentofte Denmark, guaranteed to be free of hepatitis B surface antigen and human immunodeficiency virus (HIV) antibody), subjected to sterile filtration, checked for sterility and pyrogens, and kept at $-20^{\circ} \mathrm{C}$ until use. All experiments were carried out using the same peptide batch.

EXPERIMENTAL PROCEDURE

After an overnight fast a gastric sump tube (Andersen tube AN 10, New York, USA) was placed in the antrum under fluroscopic control, and the stomach was emptied. Throughout the experiment a non-absorbable tracer, ${ }^{57} \mathrm{Co}$-cobalamin (Amersham, UK) dissolved in $1000 \mathrm{ml} 0.9 \%$ saline containing 1.25 mg cobalamin and $1 \%$ human serum albumin, was infused intragastrically at a rate of $1 \mathrm{ml} /$ min (approximately $22 \mathrm{kBq} / \mathrm{h}$ ) through a separate polyvinyl catheter attached to the gastric tube. Gastric juice was aspirated in 15 minute periods by intermittent suction producing a subatmospheric pressure of 150 $\mathrm{mm} \mathrm{Hg}$. An equilibration period of 30 minutes was followed by a basal period of 30 minutes. Pentagastrin (Peptavlon; Zeneca Ltd, Macclesfield, Cheshire, UK) was then infused intravenously at a dose of $150 \mathrm{ng} / \mathrm{kg} / \mathrm{h}$ for three hours. After 60 minutes of pentagastrin stimulation GLP-1 (7-36 amide) was infused for 60 minutes at a rate of $1 \mathrm{pmol} / \mathrm{kg} / \mathrm{min}$. After termination of the GLP-1 (7-36 amide) infusion, the pentagastrin infusion was continued for another 60 minutes.

\section{LABORATORY ANALYSIS}

The acidity of the gastric samples was determined by titration with $0 \cdot 1 \mathrm{~mol} / 1 \mathrm{NaOH}$ to $\mathrm{pH} 7.4$ at $37^{\circ} \mathrm{C}$ using a titrator TT2, ABU 80 autoburet, Radiometer, Copenhagen, Denmark). The radioactivity of ${ }^{57} \mathrm{Co}$ in each gastric sample was measured in a gamma spectrometer and used to calculate the recovery of the gastric juice volume. Subsequently, acid secretory rates were corrected for this recovery. Osmolarity as an index of duodenogastric reflux was determined by freezing point reduction. ${ }^{21}$

\section{BLOOD SAMPLES}

Blood samples were drawn from an antecubital vein every 30 minutes until the infusion of GLP-1 (7-36 amide) was started; then blood samples were drawn every 15 minutes throughout the experiment. Blood was drawn into chilled tubes containing EDTA and aprotinin $\left(\right.$ Trasylol $^{\circledR}$, Bayer, Leverkusen, Germany; $1000 \mathrm{KIU} / \mathrm{ml}$ ) and centrifuged at $4^{\circ} \mathrm{C}$; plasma was stored at $-20^{\circ} \mathrm{C}$ until analysed.

\section{RADIOIMMUNOASSAYS}

Human GLP-1 (7-36 amide) was measured using synthetic GLP-1 (7-36 amide) as a standard (Peninsula), ${ }^{125} \mathrm{I}$-labelled GLP-1 (7-36 amide), and antiserum 89390. ${ }^{7}$ The antibody has an absolute requirement for the amidated C-terminus of the molecule for binding. Blood glucose was determined by the hexokinase method. ${ }^{22}$

\section{STATISTICAL ANALYSIS}

All results are presented as means (SEM). The mean acid output in the basal period (0-30 minutes), the two last 15 minute periods during pentagastrin stimulation alone (60-90 minutes), during GLP-1 (7-36 amide) infusion (120-150 minutes), and after GLP-1 (7-36 amide) infusion (180-210 minutes) were used for statistical analysis. The significance between groups was evaluated by analysis of variance (ANOVA) followed by Newman-Keul's multiple range test; $p<0.05$ was considered significant.

\section{Results}

The recovery of the gastric marker averaged 99 (2) $\%$ in the young controls, $100(4) \%$ in the age matched controls, and 96 (3)\% in the patients (not significantly different). Osmolarity (Table I) increased slightly in all subjects as a consequence of the pentagastrin infusion, but there were no significant differences between the groups and no effect of the GLP-1 (7-36 amide) infusion, indicating that differences in duodenogastric reflux did not influence the results.

Figures 1 and 2 show the acid secretion. In the controls acid secretion increased from $1 \cdot 1$ $(0 \cdot 3) \mathrm{mEq} / 15 \mathrm{~min}$ in the basal state to $4 \cdot 8(0 \cdot 5)$ $\mathrm{mEq} / 15 \mathrm{~min}$ in the young group and from $1 \cdot 2$ $(0.3) \mathrm{mEq} / 15 \mathrm{~min}$ to $6.2(1.5) \mathrm{mEq} / 15 \mathrm{~min}$ in the old group during infusion of pentagastrin. The GLP-1 (7-36 amide) infusion significantly decreased acid secretion to $3.3(0.5) \mathrm{mEq} / 15$ min and $4.6(1.1) \mathrm{mEq} / 15 \mathrm{~min}$ respectively. After termination of the GLP-1 (7-36 amide) infusion, acid secretion returned to preinfusion concentrations $(5 \cdot 0(0.6) \mathrm{mEq} / 15 \mathrm{~min}$ and 5.9 $(1.2) \mathrm{mEq} / 15 \mathrm{~min})$. In the patients basal acid secretion averaged $0 \cdot 1(0.05) \mathrm{mEq} / 15 \mathrm{~min}$. Pentagastrin increased acid secretion to 1.9 $(0.4) \mathrm{mEq} / 15 \mathrm{~min}$, but GLP-1 (7-36 amide) had no effect on this stimulated rate of secretion $(1.8(0.3) \mathrm{mEq} / 15 \mathrm{~min}$ during

TABLE I Osmolarity (mosm $/$ ) of gastric juice in controls and patients during submaximal pentagastrin stimulation before and after (period 1 and 3) concurrent GLP-1 (7-36 amide) infusion (period 2)

\begin{tabular}{llll}
\hline & $\begin{array}{l}\text { Young controls } \\
(n=8)\end{array}$ & $\begin{array}{l}\text { Old controls } \\
(n=6)\end{array}$ & $\begin{array}{l}\text { Patients } \\
(n=8)\end{array}$ \\
\hline Basal & $205(30)$ & $196(9)$ & $234(7)$ \\
Period 1 & $257(12)$ & $256(17)$ & $238(8)$ \\
Period 2 & $246(11)$ & $243(24)$ & $244(6)$ \\
Period 3 & $233(13)$ & $242(18)$ & $237(7)$ \\
\hline
\end{tabular}

Values are expressed as means (SEM).

No significant differences were found within or between experiments. 


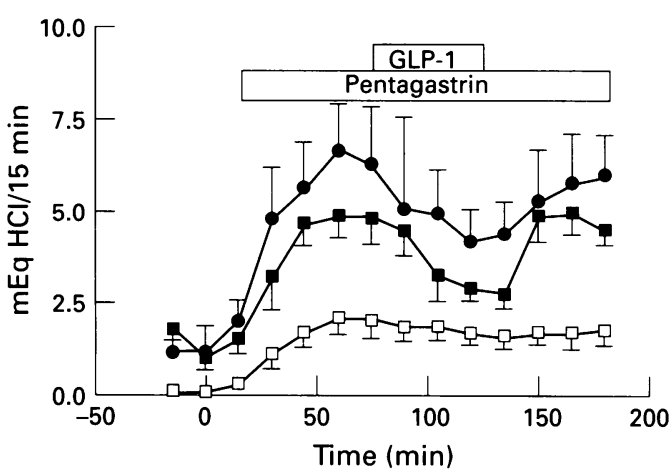

Figure 1: Acid secretion (mean (SEM)) in response to infusion of pentagastrin and GLP-1 (7-36 amide) as indicated by the horizontal bars: old controls $(\bullet ; n=6)$, young controls ( $\square ; n=8)$, and vagotomised subjects ( $\square$; $n=8$ ).

GLP-1 (7-36 amide) infusion and 1.8 (0.4) $\mathrm{mEq}$ during the last 60 minutes). Figure 3 shows that GLP-1 (7-36 amide) infusion increased plasma concentrations of GLP-1 (7-36 amide) from 5 (1) $\mathrm{pmol} / 1$ to a plateau of 42 (6) $\mathrm{pmol} / \mathrm{l}$ and 58 (6) $\mathrm{pmol} / \mathrm{l}$ in the young and old control groups, respectively, and from 7 (1) $\mathrm{pmol} / \mathrm{l}$ to 72 (6) $\mathrm{pmol} / \mathrm{l}$ in the patients. There was no significant difference between the plateaux in the patients and the old controls. The GLP-1 (7-36 amide) infusion significantly and equally effectively decreased blood glucose concentrations in all groups (Table II).

Six out of eight vagotomised subjects were $H$ pylori positive, whereas one out of the six old controls and one out of the eight young controls were positive. In both of the two positive control subjects GLP-1 (7-36 amide) clearly inhibited gastric acid secretion. There was no inhibition by GLP-1 (7-36 amide) in any of the vagotomised subjects regardless of $H$ pylori status.

\section{Discussion}

The present study shows that the inhibitory effect on pentagastrin stimulated acid secretion

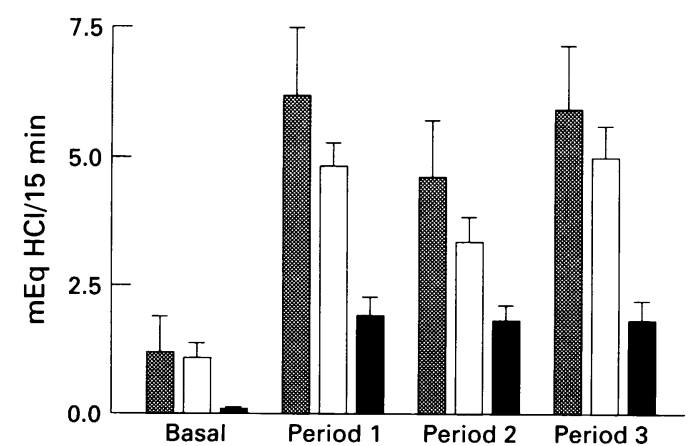

Figure 2: Effects of pentagastrin and GLP-1 (7-36 amide) infusion on acid secretion (mean (SEM)) in old controls (white columns; $n=6$ ), young controls (hatched columns $n=8$ ), and vagotomised subjects (dark columns; $n=8$ ). The results from the basal period are the means of secretion in the 30 minute period immediately before pentagstrin infusion. The secretion in period 1 is the secretion after 60-90 minutes pentagastrin secretion. Period 2 represents secretion after 30 minutes GLP-1 infusion (120-150 min), and period 3 secretion after termination of GLP-1 (7-36 amide) infusion (180-210 min).

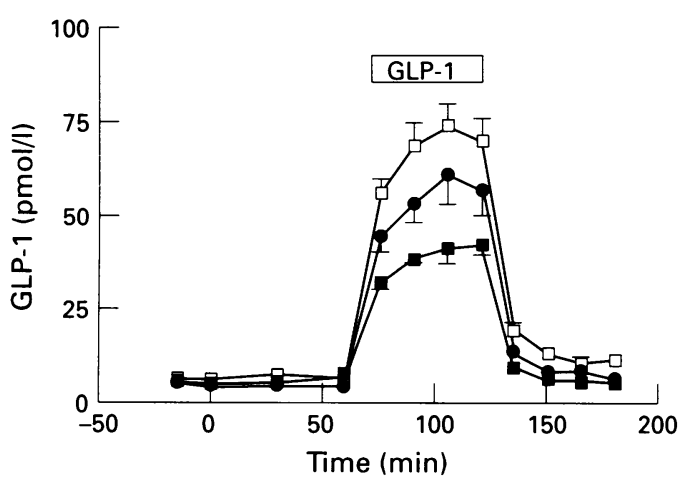

Figure 3: GLP-1 (7-36 amide) concentrations (mean

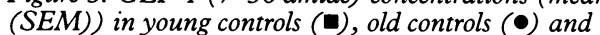
vagotomised subjects (ㅁ) in response to intravenous infusion of GLP-1 (7-36 amide) at $1 \mathrm{pmol} / \mathrm{kg} / \mathrm{min}$.

in humans ${ }^{16}$ of GLP-1 (7-36 amide), infused in an amount that increases its plasma concentration to concentrations similar to those seen during meal ingestion, is lost after vagotomy. In the young controls the GLP-1 (7-36 amide) infusion caused a 33 (6)\% reduction in acid secretion as expected, ${ }^{16} 17$ and in the old controls acid secretion decreased to 74 (3) \% of plateau values, excluding that the lack of inhibition in the older vagotomised subjects was a consequence of age. Besides, the blood glucose lowering effect of GLP-1 (7-36 amide), which is thought to reflect a direct effect of GLP-1 (7-36 amide) on the pancreatic islet cells, ${ }^{13}$ was similar in all three groups. In a recent study, Olbe et $a l^{23}$ found that the inhibition of gastric acid elicited by antral distension was lost in patients infected with $H$ pylori. Six out of our eight vagotomised patients were $H$ pylori positive, but the remaining two, as in the others, failed to show inhibition of acid secretion with GLP-1 (7-36 amide). Furthermore, in both of the two positive controls GLP-1 (7-36 amide) was fully effective. A $H$ pylori infection, therefore, is not likely as an explanation of the lack of effect of GLP-1 (7-36 amide) after vagotomy. Hypothetically, vagotomised subjects might be less sensitive to GLP-1 (7-36 amide) than normal subjects. However, we used an infusion rate that in normal subjects is maximally or near maximally effective. ${ }^{24}$ In addition, despite identical rates of infusion in all groups, the GLP-1 (7-36 amide) concentrations obtained in the vagotomised subjects tended to be higher than in the old controls and were significantly higher than in the young controls. Thus we find it unlikely that an inadequate

TABLE II Blood glucose (mmoll) in controls and vagotomised subjects during submaximal pentagastrin stimulation before and after (period 1 and 3) concurrent GLP-1 (7-36 amide) infusion (period 2)

\begin{tabular}{llll}
\hline & $\begin{array}{l}\text { Young controls } \\
(n=8)\end{array}$ & $\begin{array}{l}\text { Old controls } \\
(n=6)\end{array}$ & $\begin{array}{l}\text { Patients } \\
(n=8)\end{array}$ \\
\hline Period 1 & $5 \cdot 2(0 \cdot 4)$ & $4 \cdot 5(0 \cdot 2)$ & $5 \cdot 1(0 \cdot 4)$ \\
Period 2 & $4 \cdot 4(0 \cdot 2)^{\star}$ & $4 \cdot 0(0 \cdot 1)^{\star}$ & $4 \cdot 1(0 \cdot 4)^{\star}$ \\
Period 3 & $5 \cdot 4(0 \cdot 3)$ & $4 \cdot 3(0 \cdot 1)$ & $4 \cdot 8(0 \cdot 4)$
\end{tabular}

Values are expressed as means (SEM). ${ }^{\star} \mathrm{p}<0.05 v$ periods 1 and 3 . 
infusion rate rather than vagotomy itself explains the lack of effect. The higher concentrations of GLP-1 (7-36 amide) obtained in the older subjects may reflect a decreasing rate of metabolism of GLP-1 (7-36 amide) with age. We therefore conclude that, in humans, GLP-1 (7-36 amide) is fully effective on neurally induced acid secretion, but ineffective on purely hormonally stimulated secretion. This seems to indicate that GLP-1 (7-36 amide) does not act directly on the gastric mucosa, but interacts with vagal pathways. This could involve GLP-1 (7-36 amide) receptors associated with vagal afferents, central nervous sites, or transmission in vagal efferents. In experiments with isolated perfused preparations of the porcine stomach ${ }^{25}$ we have been unable to detect effects of intraarterially infused GLP-1 (7-36 amide) at a concentration of $10^{-9} \mathrm{~mol} / \mathrm{l}$ on pentagastrin or vagally induced acid secretion (in six perfusion experiments, unpublished studies by the authors) whereas GLP-1 (7-36 amide) effectively inhibited vagally induced acid secretion in anaesthetised pigs. ${ }^{26}$ Similarly, we were unable to find inhibitory or other effects of GLP-1 (7-36 amide) on vagally induced pancreatic exocrine secretion in vagally innervated, isolated perfused preparations of the porcine pancreas. ${ }^{27}$ This would indicate that GLP-1 (7-36 amide) probably does not interfere with vagal efferent transmission at the level of the parasympathetic ganglia. At present, experimental evidence that GLP-1 (7-36 amide), interacts with afferent vagal fibres (as cholecystokinin $\operatorname{does}^{28}$ ) is not available. An interaction with central nervous sites seems probable, however. Several groups have noted binding sites or receptors for GLP-1 (7-36 amide) in the brain. ${ }^{29-32}$ Indeed, a receptor identical to the pancreatic GLP-1 (7-36 amide) receptor was recently cloned from human brain. ${ }^{33}$ Of particular interest is the demonstration of GLP-1 (7-36 amide) binding sites in nuclei associated with the circumventricular organ. This might indicate that GLP-1 (7-36 amide), released from the small intestine, could reach the brain via these leaks in the blood-brain barrier as recently shown for rats, ${ }^{34}$ in which intracardially injected labelled GLP-1 (7-36 amide) specifically bound to cells of the subfornical organ and the area postrema, clearly crossing the blood-brain barrier. Interestingly, both of these are associated with digestive behaviour. Clearly, further studies are needed to identify in more detail the exact site of action of this hormone, which has been proposed to act as an important effector of the "ileal brake" mechanism - that is, the inhibitory endocrine signal from the lower to the upper gastrointestinal tract. ${ }^{35}$

This study was supported by the Danish National Research Council. Inge Mortensen, Winna Stavnstrup and Lene Albæk are thanked for excellent technical assistance.

1 Mojsov S, Heinrich G, Wilson IB, Ravazzola M, Orci L Habener JF. Preglucagon gene expression in pancreas and intestine diversifies at the level of posttanslational processing. F Biol Chem 1986; 261: 11880-6.
2 Ørskov C, Holst JJ, Knuhtsen S, Baldissera FGA, Poulsen SS, Nielsen OV. Glucagon-like peptides GLP-1 and GS, Nielsen OV. Glucagon-like peptides GLP-1 and GLP-2, predicted products of the glucagon gene, are
secreted seperately from the small intestine, but not secreted seperately from the small intestin

3 Ørskov C, Holst JJ, Poulsen SS, Kirkegaard P. Pancreatic and intestinal processing of proglucagon in man Diabetologia 1987; 30: 874-81

4 Bell GI, Sanchez-Pescador R, Laybourn PJ, Najarian RC. Exon duplication and divergence in the human preglucagon gene. Nature 1983; 30: 368-71.

5 Varndell IM, Bishop A, Sikri E, Uttenthal LO, Bloom SR, Polak JM. Localization of glucagon-like peptide (GLP) immunoreactants in human gut and pancreas using light and electron microscopic immunocytochemistry. $f$ Histochem Cytochem 1990; 33: 1080-6.

6 Elliott RM, Morgan LM, Tredger JA, Deacon S, Wright J, Marks V. Glucagon-like-1 (7-36) amide and glucosedependent insulinotropic polypeptide secretion in response to nutrient ingestion in man: acute post-prandial and 24-h secretion patterns. F Endocrinol 1993; 138: 159-66.

7 Ørskov C, Rabenhøj L, Wettergren A, Kofod H, Holst JJ. Production and secretion of amidated and glycineextended glucagon-like peptide-1 (GLP-1) in man. Diabetes 1994; 43: 535-9.

8 Ørskov C, Wettergren A, Holst JJ. The diurnal secretion of the incretin hormones glucagon-like peptide-1 (GLP-1) and gastric inhibitory polypeptide (GIP) is correlated with the secretion of insulin in normal man. Scand $f$ Gastroenterol 1996; 31: 665-70.

9 Göke R, Richter G, Kolligs F, Fehmann HC, Arnold R, Göke $B$. How do individual meal constituents influence the release of GLP-1 in humans [abstract]? Digestion the release of

10 Kreymann B, Ghatei MA, Williams G, Bloom SR. Glucagon-like peptide-1 7-36: a physiological incretin in man. Lancet 1987; ii: $1300-3$

11 Holst JJ, Ørskov C, Nielsen OV, Schwartz TW. Truncated glucagon-like peptide-1, an insulin-releasing hormone from the distal gut. FEBS Lett 1987; 211: 169-74.

12 Komatsu R, Matsuyama T, Namba M. Glucagonostatic and insulinotropic action of glucagonlike peptide-1 (7-36)-amide. Diabetes 1989; 38: 902-5.

13 Hvidberg A, Toft Nielsen M, Hilsted J, Ørskov C, Holst JJ. Effect of glucagon-like peptide-1 (proglucagon 78-107 amide) on hepatic glucose production in healthy man. amide) on hepatic glucose
Metabolism 1994; 43: 104-8.

14 Nauck M, Heimesaat MM, Ørskov C, Holst JJ, Ebert R, Creutzfeldt W. Preserved incretin activity of glucagon-like peptide-1 [7-37 amide] but not of synthetic human gastric inhibitory polypeptide in patients with type-2 diabetes mellitus. F Clin Invest 1993; 91: 301-7.

15 Ørskov C. Glucagon-like peptide-1 a new hormone of the entero-insular axis. Diabetologia 1992; 35: 701-11.

16 Schjoldager BGT, Mortsen PE, Christiansen J, Ørskov C, Holst JJ. GLP-1 (glucagon-like peptide 1) and truncated GLP-1, fragments of human proglucagon, inhibit gastric acid secretion in man. Dig Dis Sci 1989; 35: 703-8.

17 O'Halloran DJ, Nikou GC, Kreymann B, Ghatei MA, Bloom SR. Glucagon-like peptide-1 (7-36)- $\mathrm{NH}_{2}$ : a physiological inhibitor of gastric acid secretion in man. $\mathcal{F}$ physiological inhibitor of gastric

18 Wettergren A, Schjoldager B, Mortensen PE, Myhre J, Christiansen J, Holst JJ. Truncated GLP-1 (proglucagon 78-107-amide) inhibits gastric and pancreatic functions in man. Dig Dis Sci 1993; 38: 665-73.

19 Wettergren A, Petersen H, Ørskov C, Christiansen J, Sheikh SP, Holst JJ. Glucagon-like peptide-1 7-36 amide and peptide YY from the L-cell of the ileal mucosa are potent inhibitors of vagally induced gastric acid secretion in man. Scand $\mathcal{F}$ Gastroenterol 1994; 29: 501-5.

20 Andersen LP, Espersen F, Souckova A, Sedlackova M, Soucek A. Isolation and preliminary evaluation of a low-molecular-mass antigen preparation for improved detection of Helicobacter pylori immunoimproved detection of Helicobacter pylori immuno-
globulin G antibodies. Clin Diagn Lab Immunol 1995; 2: globulin

21 Henriksen FW, Jögensen SP, Möller S. Interaction between secretin and cholecystokinin on inhibition of gastric secretion in man. Scand F Gastroenterol 1974; 9: $735-40$.

22 Widdonson GM, Penton JR. Determination of serum and plasma glucose on "autoanalyzer II" by use of hexokinase reaction. Clin Chem 1972; 18: 299-300.

23 Olbe L, Hamlet A, Dalenbäck J, Fändriks L. A mechanism by which Helicobacter pylori infection of the antrum contributes to the development of duodenal ulcer. Gastroenterology 1996; 110: 1386-94.

24 Wettergren A, Maina P, Boesby S, Holst JJ. The effect of GLP-1 and PYY on acid secretion in man [abstract]. Regul Pept 1996; 64: 208.

25 Holst JJ, Skak-Nielsen T, Ørskov C, Poulsen SS. Vagal control of the release of somatostatin, vasoactive intestinal polypeptide, gastrin releasing peptide, and $\mathrm{HCl}$ from polypeptide, gastrin releasing peptide, and $\mathrm{HCl}$ from
porcine non-antral stomach. Scand $\mathcal{J}$ Gastroenterol 1992; 27: $677-85$.

26 Holst JJ, Wettergren A, Wøjdemann M, Poulsen SS, Ørskov C. Glucagon-like peptide-I (GLP-1): an important C. Glucagon-like peptide-I (GLP-1): an important
enterogastrone acting via the central nervous system. enterogastrone acting via the central
Hepatogastroenterology 1995; 42: 1071 .

27 Holst JJ, Rasmussen TN, Harling H, Schmidt P. Effect of intestinal inhibitory peptides on vagally induced secretion from isolated perfused porcine pancreas. Pancreas 1993 8: $80-7$. 
28 Lorenz DN, Goldman SA. Vagal mediation of the cholecystokinin satiety effect in rats. Physiol Behav 1982; 29: 599-604.

29 Uttenthal LO, Toledano A, Blasquez E. Autoradiographic localization of receptors for glucagon-like peptide-1 (7-36) amide in rat brain. Neuropeptides 1992; 21: $143-6$.

30 Shimizu I, Hirota M, Obhoshi C, Shima K. Identification and localization of glucagon-like peptide- 1 and tion and receptor in rat brain. Endocrinology 1987; 121: its receptor

31 Göke R, Larsen PJ, Mikkelsen JD, Sheikh S. Distribution of GLP-1 binding sites in the rat brain. Evidence that exendin 4 is a ligand of brain GLP-1 binding sites. Eur f Neurosci 1995; 7: 2294-300.
32 Turton MD, O'Shea D, Gunn I, et al. A role for glucagonlike peptide-1 in the regulation of feeding. Nature 1996; 379: 69-72.

33 Wei Y, Mojsov S. Tissue-specific expression of the human receptor for glucagon-like peptide-1: brain, heart and pancreatic forms have the same deduced amino acid sequences. FEBS Lett 1995; 358: 319-24.

34 Ørskov C, Poulsen SS, Møller M, Holst JJ. GLP-1 receptors in the subfornical organ and the area postrema are accessible to circulating glucagon-like peptide-1. Diabetes 1996; 45: 832-5.

35 Layer P, Holst J, Grandt D, Geobell $H$. Ileal release of glucagon-like peptide-1 (GLP-1): association with inhibition of gastric acid secretion in humans. Dig Dis Sci 1995; 40: 1074-82. 